\title{
後浜を越える波浪による陸向き土砂移動に関する実験
}

\section{Experimental Study on Sediment Transport Caused by Overtopping Waves across a Backshore}

\author{
野中久敬 ${ }^{1} \cdot$ 高川智博 $^{2} \cdot$ 佐藤愖司 $^{3}$ \\ Hisanori NONAKA, Tomohiro TAKAGAWA and Shinji SATO
}

\begin{abstract}
Laboratory experiments were performed on the sediment transport on backshore, which was caused by solitary waves as well as cyclic waves. Measurements were conducted for overtopped volume of water and sand, temporal variations of horizontal water particle velocities, surface elevations and suspended sediment concentration. Meyer-Peter-Muller's formula and Lane-Kalinske's formula were found to be consistent with the sand transport rate caused by long waves but inconsistent for solitary wave. Sediment suspension and convection on the foreshore due to breaking was found to be important to estimate the sand transport due to solitary wave. The saturation of suspended sand concentration was observed when the height of the incident solitary wave exceeded $7 \mathrm{~cm}$.
\end{abstract}

\section{1. はじめに}

2011 年に起きた東北地方太平洋沖地震による津波で は, 津波が運んだ土砂やへドロといった堆積物が問題と なっており，仙台市では津波が運んだ土砂だけでがれき の量を上回る見込みである。このような土砂は交通を分 断し, 被災地の復興の妨げになっており, 被災地の復興 計画を立てる上で, 津波によって内陸部に輸送された土 砂量を定量的に予測することが重要である.さらに近年 問題となっている海岸侵食を予測する上でも, 砂堆や砂 州を越える波浪による土砂移動量を定量的に予測するこ とが重要である（高川ら，2010）。本研究は後浜を越流 するように越える波による土砂移動量を断面水路におけ る実験により定量的に評価し, 砂州や砂堆の土砂移動量 の予測に結びつけるものである.

\section{2. 実験}

\section{（1）後浜を越える波浪による越波量と漂砂量の測定}

実験には, 長さ $30.0 \mathrm{~m}$, 深さ $0.8 \mathrm{~m}$, 幅 $0.6 \mathrm{~m}$ の二次元造 波水路を用いた。全体図を図-1に示す。造波板から $13.2 \mathrm{~m}$ の地点よりも岸側では水路を沿岸方向に幅 $0.45 \mathrm{~m}$ の 部分と $0.15 \mathrm{~m}$ の部分に分割し, 粒径 $\mathrm{D}_{50}=0.13 \mathrm{~mm}$ の砂を使 用し, 幅 $0.15 \mathrm{~m}$ の部分に勾配 $1 / 10$ の前浜部分と長さ $2 \mathrm{~m}$ の 水平な後浜部分からなる初期砂浜地形を作った. $\mathrm{X}=20.5 \mathrm{~m}$ の地点を $\mathrm{X} 0$ 地点とし, 波を越波させた後, X0 地点と $X=21 \mathrm{~m}$ 地点の間の砂と捕捉箱に捉えられた砂を乾 燥計量し, 波作用前の砂重量を差し引いて, X0地点を通
1 学生会員
東京大学大学院 工学系研究科社会基盤学 専攻
2 正会員 理博
3 フェロー 工博
東京大学助教 工学系研究科社会基盤学 専攻 東京大学教授 工学系研究科社会基盤学 専攻

過した漂砂量を求めた。同時に捕捉箱で捉えた水を計量 し, 越波量を求めた.

$\mathrm{L}$ 字型の木枠は, 上層の砂と低層の砂の混合を防ぐた めのものである。造波する波は, 孤立波, 長周期波, 長 周期波と短周期波の混在波の 3 種類とした. 計量の誤差 を少なくするため, 孤立波は3 回, 長周期波, 長周期 波 + 短周期波の混在波は 15 周期分造波し, 十分な漂砂量 と越波量を確保した。実験条件は表-1のとおりである. 長周期波と短周期波の混在波の短周期性分は周期 $0.8(\mathrm{~s})$ である. また, X0地点を越える流れの様子を, 八イスピ ードカメラを用いて200fpsで撮影した。

表-1 実験条件

\begin{tabular}{c|c|c|c}
\hline \multirow{4}{*}{ 孤立波 } & $\begin{array}{c}\text { 一様水深部 } \\
\text { 波高 }(\mathrm{cm})\end{array}$ & 周期 $(\mathrm{s})$ & 静水深 $(\mathrm{cm})$ \\
\cline { 2 - 4 } & 7.6 & - & 45 \\
\cline { 2 - 4 } & 7.4 & - & 45 \\
\cline { 2 - 4 } & 7.0 & - & 45 \\
\cline { 2 - 4 } & 6.7 & - & 45 \\
\cline { 2 - 4 } & 6.2 & - & 45 \\
\cline { 2 - 4 } & 5.6 & - & 45 \\
\hline \multirow{2}{*}{\begin{tabular}{l} 
の洁期波と短周期波 \\
\cline { 2 - 4 }
\end{tabular}} & 5.1 & 4 & 47 \\
\hline \multirow{2}{*}{ 長周期波 } & 8.8 & 4 & 50 \\
\cline { 2 - 4 } & 7.0 & 4 & 50 \\
\hline
\end{tabular}

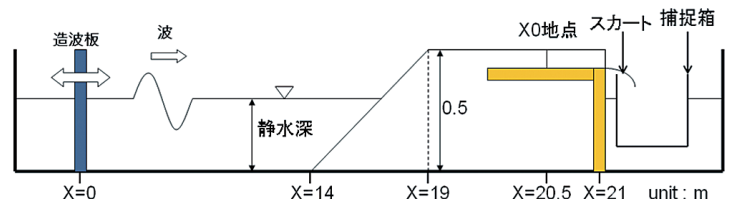

図-1 二次元造波水路 
表-2 長周期波、長周期波と短周期波の混在波の漂砂量と一 波あたりの越波量

\begin{tabular}{c|c|c|c|c}
\hline & Case1 & Case2 & Case3 & Case4 \\
\hline 漂砂量 $\mathrm{q}(\mathrm{g})$ & 7.3 & 1.3 & 9.9 & 41.3 \\
\hline $\begin{array}{c}\text { 一波あたりの } \\
\text { 越波量Q(g) }\end{array}$ & 1300 & 1029 & 2213 & 1983 \\
\hline
\end{tabular}

表-3 孤立波の漂砂量と一波あたりの越波量

\begin{tabular}{c|c|c}
\hline $\begin{array}{c}\text { 一様水深部波高 } \\
\mathrm{H}(\mathrm{cm})\end{array}$ & $\begin{array}{c}\text { 漂砂量 } \\
\mathrm{q}(\mathrm{g})\end{array}$ & $\begin{array}{c}\text { 一波あたりの越波量 } \\
\mathrm{Q}(\mathrm{g})\end{array}$ \\
\hline 7.6 & 291 & 3236 \\
\hline 7.4 & 284 & 2911 \\
\hline 7.0 & 220 & 2241 \\
\hline 6.7 & 203 & 2367 \\
\hline 6.2 & 167 & 2031 \\
\hline 5.6 & 90 & 1181 \\
\hline 5.1 & 45 & 804 \\
\hline
\end{tabular}

\section{3. 実験結果}

\section{（1）長周期波, 長周期波と短周期波の混在波の漂砂量} と越波量

15 周期分の長周期と短周期の混在波，長周期波を造波 し，一波あたりの漂砂量と一波あたりの越波量を表-2に まとめた。水深 $47 \mathrm{~cm}$ で長周期と短周期の混在波をあて た場合を case1，長周期波をあてた場合を case2 とし，水 深 $50 \mathrm{~cm}$ で長周期と短周期波の混在波をあてた場合を case3，長周期波をあてた場合を case4 とした.

\section{(2) 孤立波の漂砂量と越波量}

孤立波を 3 回造波し，一波あたりの漂砂量と一波あた りの越波量を表-3にまとめた。

\section{X0地点における流速と水深の解析結果}

\section{（1）長周期波, 長周期と短周期の混在波の場合の流速 補正}

撮影した画像が水路側面からのものなので，特に濃度 が濃い時は水路の中央に比べて流速の小さな側面近傍の 流速を反映し，画像解析による流速測定では流速が過小 評価される可能性がある。そこで次のように流速補正を 行った.

PIV 手法をもちいてX0地点の流速と水深の時間変化を 求め, PIV手法によって計測したX0地点における流速を $u$, 水深を $h$ 'とし, 実際の流速を $u$, 水深を $h$ とすると, 水深についてはPIV 手法による誤差は少ないので $h$ と $h$, は等しいとしてょく，流速に関しては $u=a u$ とおくこと ができる。このことから実際の越波量 $Q$ と計算上の越波 量 $Q$ は式（1）のような関係がある.

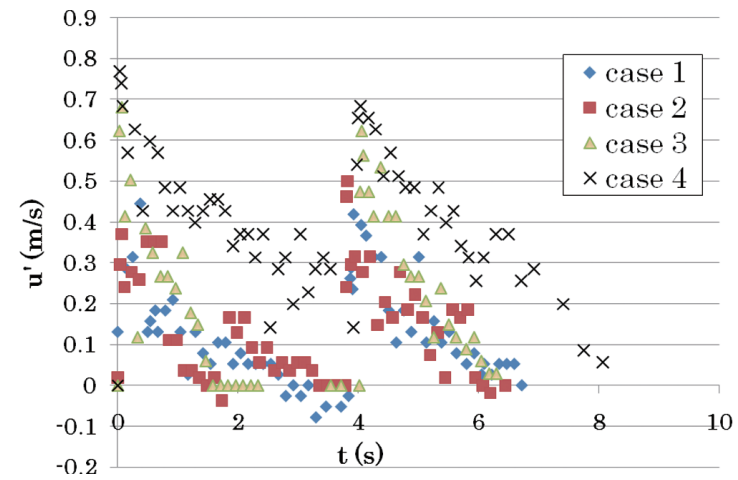

図-2ＰIVで測定したX0地点の流速 $\mathrm{u}^{\prime}$ の時間変化

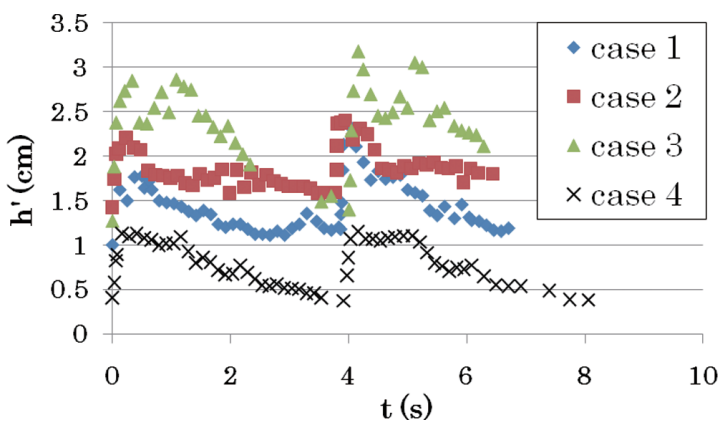

図-3 PIVで測定したX0地点の水深h'の時間変化

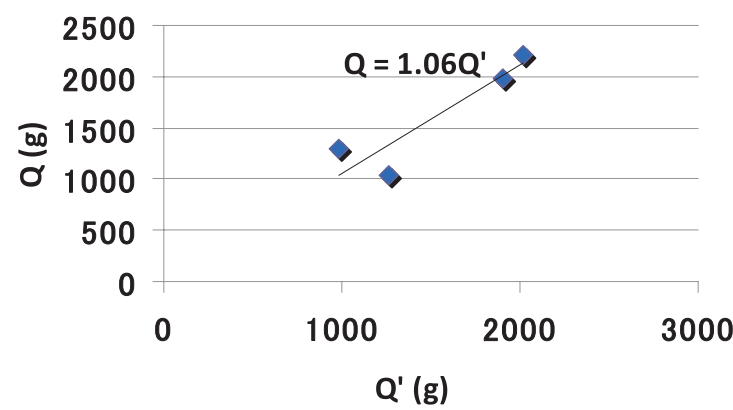

図-4 周期波をあてたときの計算上の越波量 $\mathrm{Q}$ ’と実際の越波 量 $\mathrm{Q}$ の関係

$$
Q=\int u B h d t=\int a u^{\prime} B h^{\prime} d t=a Q^{\prime}
$$

図-2, 図-3 は計 15 回の越波のうち 2 回分をとりだし, $u$ と $h^{\prime}$ の時間変化をプロットしたものである.この $u^{\prime}$ と $h^{\prime}$ を式（1）に代入し $Q$ と $Q$ 'を求めた。各波の $Q$ と $Q$ 'を プロットした図-4より長周期，長周期 + 短周期の混在波 の場合の流速補正係数は，1.06 と決定できた。長周期, 長周期 + 短周期の混在波の場合，X0地点での浮遊砂濃度 が小さく水路中央の流速が計測できたためだと考えるこ とができる。

\section{（2）孤立波の場合の流速補正}

孤立波の場合も長周期波，長周期と短周期の混在波の 
場合と同様にして流速補正を行った。図-5は孤立波の波 高（H）ごとのX0地点でのPIVで計測した流速の変化で あり図-6はX0地点における水深の時間変化である.

図-7 から孤立波の流速の補正係数を 1.53 と求めること ができた.ここで周期波のものに比べて補正係数が大き いのは，孤立波による越波流の浮遊砂濃度が高いため， 画像解析による流速測定の際流速の小さな側面近傍の流 速を反映してしまったからである。

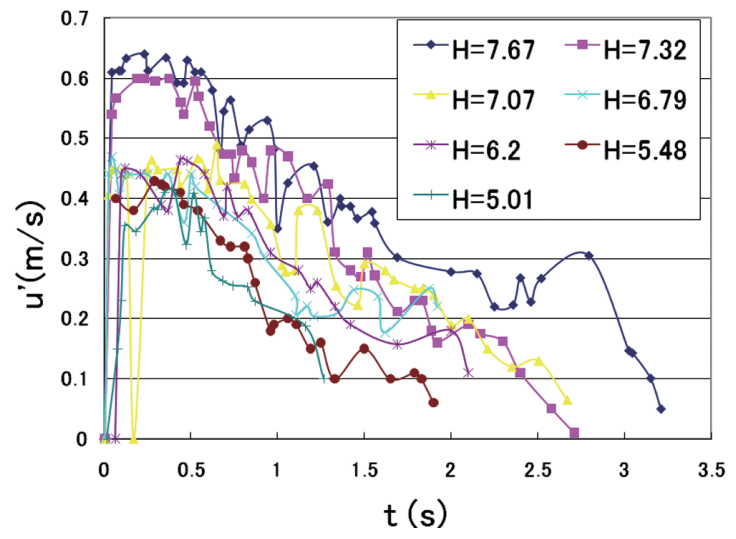

図-5 PIVで測定したX0地点における流速 u’の時間変化 (Hは孤立波の波高)

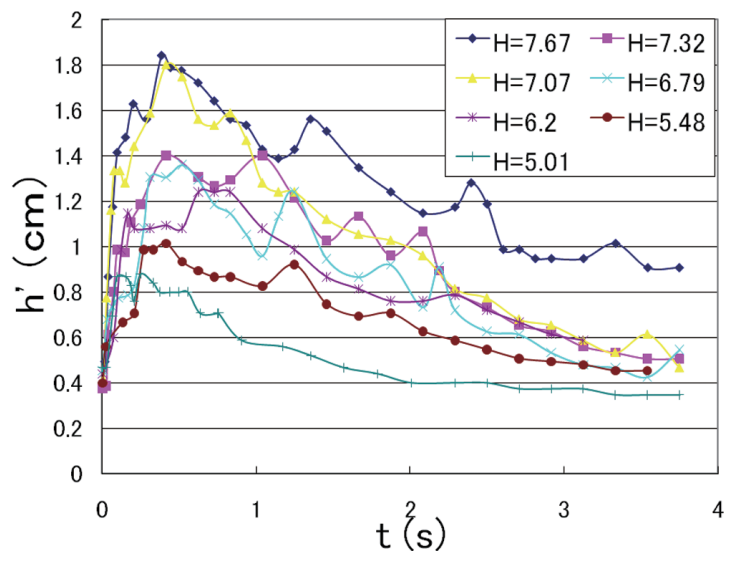

図-6 PIVで測定したX0地点における水深h'の時間変化 (Hは孤立波の波高)

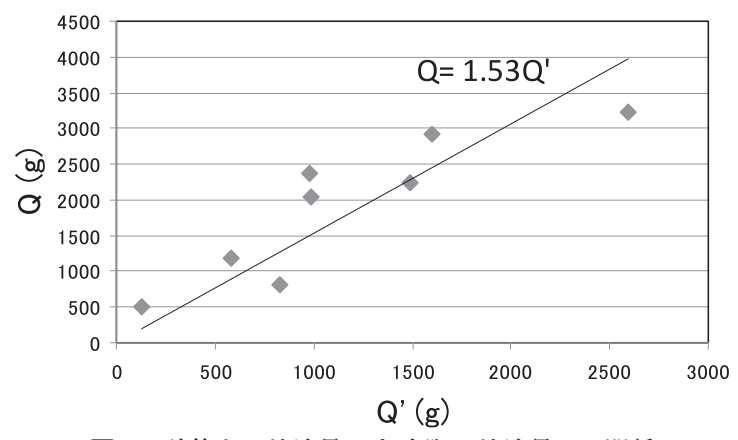

図-7 計算上の越波量 $\mathrm{Q}$ 'と実際の越波量 $\mathrm{Q}$ の関係

\section{5. 漂砂量の推定}

4 章では， 3 章で補正した流速 $u^{\prime}$ と水深 $h^{\prime}(=h)$ を用い て漂流砂量を推定する.

（1）長周期波，長周期と短周期の混在波の場合

\section{a) 掃流砂の推定}

推定掃流砂量はMeyer P Peter - Mullerの式を用いて求 めた。水理公式集 (1971, p203)によると Meyer • Peter · Mullerの式は式（2）のように表すことができる.

$$
q_{b}=8 \sqrt{\left(\frac{\rho_{s}}{\rho_{w}}-1\right) g d^{3}}\left(\psi-\psi_{c}\right)^{\frac{3}{2}}
$$

ただし， $q_{b}$ は単位時間，単位幅当たりの掃流砂量， $d$ は土砂の平均粒径, $\rho_{z}$ は土粒子密度, $\rho_{w}$ は水の密度, $g$ は重力加速度である。

またHossein Afzalimehr（2010）によると摩擦係数 $f^{\prime}$ と 水深 $h の$ 関係は式（5）であらわすことができる.

$$
1 / \sqrt{f^{\prime}}=2.03 \log \left(12.2 h / d_{90}\right)
$$

ここで $f^{\prime}$ は摩擦係数， $d_{90}=0.18 \mathrm{~mm}$ である. 計算の手順 として式（3）のhに各時点の水深を代入し, 各時点の摩 擦係数 $f^{\prime}$ を求める. 次に補正した流速 $u$ と摩擦係数 $f^{\prime}$ か ら摩擦速度 $u_{*}$ を算出し各時点の単位幅掃流砂量を求め る. 最後に単位幅掃流砂量を水路幅 $\mathrm{B}(\mathrm{B}=15 \mathrm{~cm})$ を掛け た上で時間について積分し全掃流砂量を求めた.

\section{b) 浮遊砂の推定}

浮遊漂砂量はLane・Kalinskeの式を用いて求めた。水 理公式集（1971）によるとLane・Kalinskeの式は式（4） のように表すことができる

$$
C_{0}=5.55 \Delta F\left(w_{0}\right)\left[\frac{1}{2}\left(\frac{u_{*}}{w_{0}}\right) \exp \left(-\left(\frac{w_{0}}{u_{*}}\right)^{2}\right)\right]^{1.61} \cdots
$$

ここで $u_{*}$ は摩擦速度 $(\mathrm{m} / \mathrm{s}), w_{0}$ は沈降速度 $(\mathrm{m} / \mathrm{s})$, $\Delta F\left(w_{0}\right)$ は：沈降速度 $w_{0}$ なる砂粒が河床砂磼中に占める割 合 $(\%)$ である。 今回は $100 \%$ とした， $C_{0}$ は底面の浮遊 砂濃度（ppm）である.

Lane・Kalinskeの式では浮遊砂の沈降と浮遊が平衡状 態であることを仮定しているが本実験では越波した流れ は明らかに浮遊砂が過剩であるのでここでは浮遊砂濃度 が水深にかかわらず一定で常に，濃度の一番高い底面の 浮遊砂濃度 $C_{0}$ であると仮定とした。

\section{c）周期波における浮遊砂と掃流砂の計算結果}

$q_{b}$ は掃流砂量, $q_{s}$ は浮遊砂量とすると長周期波, 長周 期と短周期の混在波の場合 $q_{b}, q_{s}$ は表-4のようにまとめ ることができる。

式（2），式（4）は通常，長い河川などに使用される 平衡状態に扔ける式である。一方，本実験では河川の河 道にあたる区間（X=15m 21m区間）が短く，各地点で 
表-4 掃流砂量と浮遊砂量

\begin{tabular}{c|c|c|c|c}
\hline & Case1 & Case2 & Case3 & Case4 \\
\hline $\mathrm{qb}(\mathrm{g})$ & 0.37 & 0.30 & 1.26 & 8.89 \\
\hline $\mathrm{qs}(\mathrm{g})$ & 0.49 & 0.39 & 2.42 & 2.41 \\
\hline $\mathrm{qb}+\mathrm{qs}(\mathrm{g})$ & 0.87 & 0.70 & 3.68 & 11.30 \\
\hline
\end{tabular}

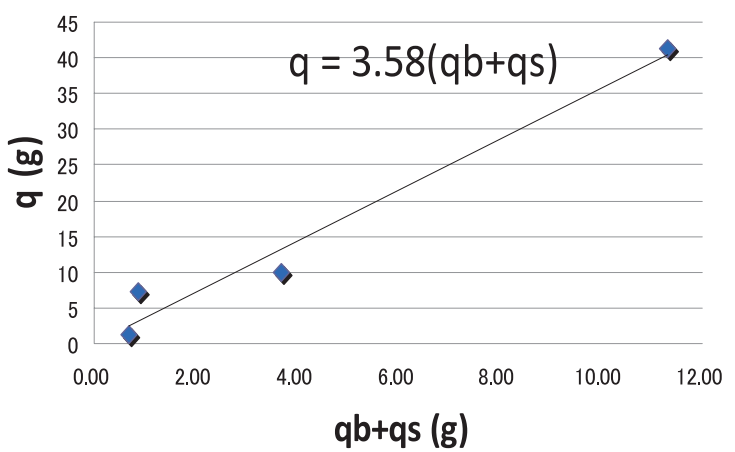

図-8 掃流砂 + 浮遊砂と漂砂の関係

沈降が十分に完了していない非平衡状態であると予想さ れる，穴のため表-2, 表-4からわかるとおり，実際の漂 砂量が掃流砂と浮遊砂の合計より大きくなった。しかし， 図-8から実際の漂砂量が掃流砂と浮遊砂の合計と線形の 関係にあることがわかり，式（2），式（4）の係数を式 (5)，式（6）のようにそれぞれ3.58倍することで浮遊砂 と掃流砂が推定できることが分かった。

$$
\begin{aligned}
q_{b} & =28.6 \sqrt{\left(\frac{\rho_{s}}{\rho_{w}}-1\right) g d^{3}}\left(\psi_{e}-\psi_{c}\right)^{\frac{3}{2}} \ldots \ldots \ldots \ldots . . . \\
C_{0} & =19.9 \Delta F\left(w_{0}\right)\left[\frac{1}{2}\left(\frac{u_{*}}{w_{0}}\right) \exp \left(-\left(\frac{w_{0}}{u_{*}}\right)^{2}\right)\right]^{1.61}
\end{aligned}
$$

\section{（2）孤立波の場合}

\section{a) 掃流砂十浮遊砂}

式（5），式（6）を使って孤立波の場合も掃流砂と浮 遊砂について求め表-5にまとめた。しかし掃流砂と浮遊 砂の合計は実際の漂砂の 1/5 1/2程度と, かなり小さい值 となってしまった。これは前浜で巻きあげられた砂の大 部分が沈降する前にX0 地点を通過しているがこの移流

表-5 孤立波の掃流砂 + 浮遊砂と漂流砂量の比較

\begin{tabular}{c|c|c}
\hline 一様水深部波高 $(\mathrm{cm})$ & 掃流砂十浮遊砂 $(\mathrm{g})$ & 実際の漂砂量 $(\mathrm{g})$ \\
\hline 7.6 & 153 & 291 \\
\hline 7.4 & 123 & 284 \\
\hline 7.0 & 54 & 220 \\
\hline 6.7 & 39 & 203 \\
\hline 6.2 & 43 & 167 \\
\hline 5.6 & 30 & 90 \\
\hline 5.1 & 20 & 45
\end{tabular}

の項を無視していたため. 漂砂量を過小評価していたた めだと考えることができる。

\section{b）巻上げ砂}

漂砂量が過小評価されてしまったので，これを補正す るために, 前浜（19 m 20.5m 地点）で巻き上げられた浮 遊砂が沈降せず全て X0 地点（20.5m地点）を通過すると 仮定して，X0地点までの累積巻上げ砂量を求めた。

巻上量の推定には高橋ら（1999）の無次元巻上量式を 用いた。

高橋ら（1999）の無次元巻上量式

$$
P / \sqrt{s g d}=0.012 \psi^{2}
$$

ここで $P$ は巻上量 $(\mathrm{m} / \mathrm{s}) S=1.65, g$ は重力加速度 $d$ は： 粒径 $(\mathrm{m}) \psi$ はシールズ数である.

$$
\psi=\frac{u_{: *}^{2}}{s g d}
$$

$\mathrm{X} 0$ 地点での摩擦速度 $u_{*}$ が $19 \mathrm{~m}$ X0 地点で一様であると 仮定すると，式（8）よりシールズ数も $19 \mathrm{~m} \sim X 0$ 地点で一 様となる.よって, 19m X0地点の河床面積を $A$ とすると, 巻き上げられた砂の量 $q_{r}$ は式（9）で表すことができる.

$$
q_{r}=\int 0.012 \psi^{2} \sqrt{s g d} \cdot A d t
$$

図-9のように波高が7 cm 以下の孤立波の場合には実際 の漂流砂量と近い值となったが, 波高 $7 \mathrm{~cm}$ 以上の孤立波

表-6 孤立波の漂砂量と巻上量

\begin{tabular}{c|c|c|c}
\hline 波高 $(\mathrm{cm})$ & $\mathrm{qr}(\mathrm{g})$ & $\mathrm{qs}+\mathrm{qb}+\mathrm{qr}(\mathrm{g})$ & 漂砂量 $\mathrm{q}(\mathrm{g})$ \\
\hline 7.6 & 369 & 523 & 291 \\
\hline 7.4 & 297 & 420 & 284 \\
\hline 7.0 & 119 & 173 & 220 \\
\hline 6.7 & 80 & 120 & 203 \\
\hline 6.2 & 96 & 139 & 167 \\
\hline 5.6 & 68 & 98 & 90 \\
\hline 5.1 & 46 & 67 & 45 \\
\hline
\end{tabular}

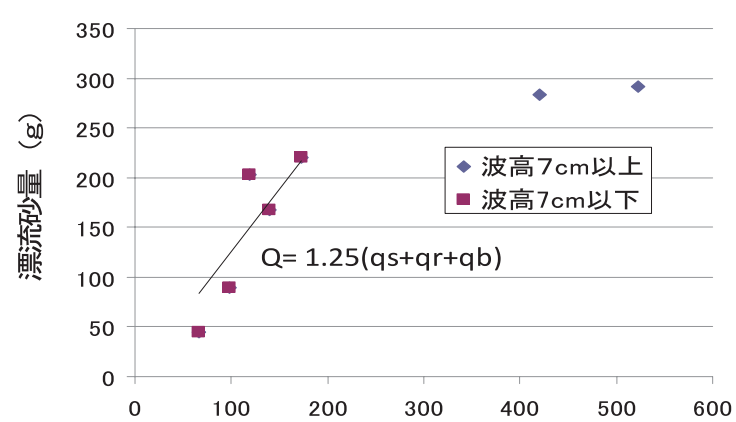

浮遊砂十巻上砂十掃流砂（g）

図-9 浮遊砂 +巻き上げ砂 +掃流砂と漂砂量の関係 


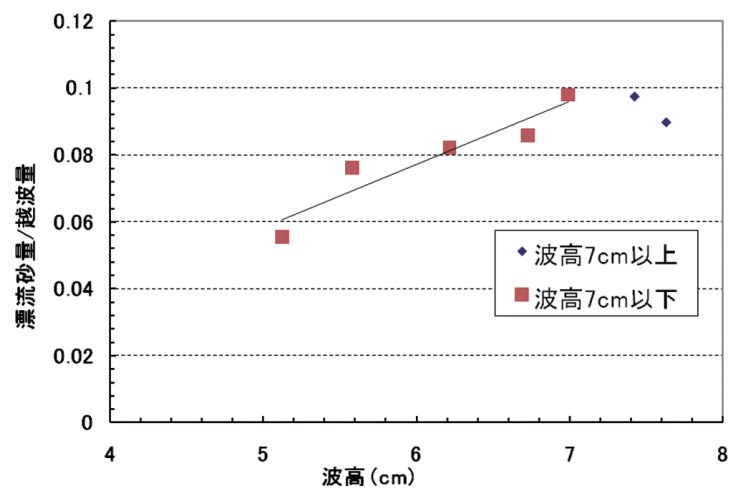

図-10 波高と漂流砂量/越波量の関係

の場合は, 実際の漂砂量は浮遊砂 + 巻きあげ砂 + 掃流砂 の $1 / 2$ 程度の值となった。図-10 は縦軸に浮遊砂濃度（実 際の漂砂量を実際の越波量で割った值)，横軸に孤立波 の波高をとったものである. 波高 $7 \mathrm{~cm}$ 以上では，浮遊砂 濃度が質量濃度 $10 \%$ で頭打ちになっていることがわか る.このことから，孤立波の場合，波高が十分に大きい と越波した流れの浮遊砂濃度が質量濃度にしておよそ $10 \%$ 飽和状態になることがわかった。

\section{6. 結論}

本研究では, 断面二次元水路を使い後浜を越える波浪 による陸向き土砂移動に関する実験を行うことにより,
漂砂量と後浜を越える波浪の水深と流速の関係について 検討し，以下の結論を得た。

(1) 長周期波や長周期と短周期の混在波などの通常の波 浪で起こされた波による漂砂量は, 掃流砂, 浮遊砂の みを考慮することで土砂移動量を精度よく評価できる ことがわかった。

（2）孤立波の場合，掃流砂，浮遊砂に加えて，前浜から の巻き上げ砂を考慮しなけれげならない.

（3）波高の大きな孤立波の場合, 越波した流れが飽和状 態となり，浮遊砂濃度が上がらなくなる. Meyer・ Peter - Mullerの掃流砂量式, Lane $\cdot$ Kalinskeの浮遊砂 量式と高橋らの巻き上げ量式を用いるとともに浮遊砂 の飽和濃度を考慮することによって越波流による土砂 移動量を精度よく評価できることが分かった。

\section{参 考 文 献}

高川智博 - 斉藤正一郎 ·上山 聡 - 田島芳満 - 劉 海江 - 武 若 聡・佐藤慎司 (2010): 台風0918号の高波浪による天 竜川河口砂州周辺の土砂移動実態の解明, pp. 601-605.

高橋智幸・首藤伸夫 - 今村文彦 - 浅井大輔 (1999)：掃流砂 層・浮遊砂層間の交換砂量を考慮した津波移動床モデル の開発, 海岸工学論文集, 第46巻, pp. 606-610.

土木学会編 (1971):水理公式集, p. 203, p. 210.

Hossein Afzalimehr, Vijay P.Singh, F.ASCE; and Elham Fazel Najafabadi (2010): Determination of Form Friction Factor Journal of Hydrologic Engineering, Vol. 15, No. 3, March 2010, pp. 237-243. 